\title{
IBN 'ASHUR AND NEGATION OF MINORITY'S CONTRIBUTION TO THE DEVELOPMENT OF NATION
}

\author{
Saifuddin Herlambanga, Budi Juliandi ${ }^{b}$ \\ aIAIN Pontianak, email: saifuddin_herlambang@yahoo.co.id \\ bUIN Jakarta, email: budi.juliandi@gmail.com
}

\begin{abstract}
The Quran promotes universal values. However, the interpretation of the Quran may potentially reduce its universality. This paper presents the concept of shürā and sadaqa in al-Tahrīr wa al-Tanwīr authored by Ibn 'Āshūr, focusing on Surah Āli 'Imrān (3): 159 and Surah al-Baqarah (2): 264. It also brings up other interpretations to provide a variety of opinions from Muslim scholars. This study builds up on the Malasevic's theory of identity politics, stating that identity politics is not only exercised by marginalized people, or minorities in the midst of a major power within a country, but also in the majority, as well as in the ruling group. This study argues that Ibn 'Āshūr's interpretation is influenced by Islamic identity politics that negate other identities. He therefore excludes non-Muslims' engagement in the process of national consolidation and development in Tunisia. This paper further maintains that, unlike Ibn 'Âshūr', the interpretation of the concept of shūrā should yield a peaceful coexistence between minorities and majorities in Muslim countries and beyond.
\end{abstract}

Keywords: Ibn 'Āshūr, political identity, Tunisa, shūrā

DOI: http://dx.doi.org/10.20414/ujis.v22i1.306

\section{Introduction}

THE RADICAL RELIGIOUS GROUPS and their repressive actions fueled by religiously sacred texts create bad impression on religion amidst of its peace teachings. Religion promotes non-violent movements, democratic civic engagement, and peace building in societies. On the hand of the radicals, religion in some countries contributes to the growth of intolerance and tyranny and escalation of communal disputes. Although religious teachings 
encourage tolerance and advocate forgiveness and mercy but they also contain elements that can be misunderstood as promoting killing, bigotry, and fanaticism. Despite the profound peace messages of every religious tradition, the fact remains that it is also filled with symbols and language of violence. ${ }^{1}$

This paper discusses one example of the Quranic interpretation that may annihilate social integration amongst people of different faith. It explores the work of Tunisian scholar Ibn 'Āshūr entiled al-Taḩrīr wa al-Tanwìr, focusing on the concept of shürā (deliberation) and șadaqa (contribution) and examining the role of non-Muslims in these fields. There are some studies about this figure. Bassām Ridwān 'Ulyān, for example, wrote Manhaj ibn 'Āshür fì al-Qirā'at fì al-Tafsìrih al-Taḩīir wa al-Tanwwìr. He focuses on the method of reading the Quran perfomed by ibn 'Āshūr through the linguistic sciences, especially in the verses contained in juz' 12. ${ }^{2}$ Muchammad describes the theory of maqāsid and the interpretive principles of Ibn 'Āshūr. The main focus of his research stems from the interpretive principles formulated by ibn 'Āshūr in his two works, Maqūșid al-Sharī'ah al-Islāmìyah and alTahrīr wa al-Tanwīr. Muchammad's thesis suggests that the idea of Ibn 'Āshūr is often used to challenge textualism and rigidity in tafsir. ${ }^{3}$ Al-Ajhuri, discusses the interpretation of ibn 'Āshūr. Although he explains the political stance of ibn 'Āshūr, especially when Bourguiba ruled Tunisia, the discussion focuses on political attitudes and the interpretation of verses on women's standing and family law, which is quite controversial. ${ }^{4}$ In one of his writings, Ghozzi discusses the career and reformist-modernist thinking of ibn 'Āshūr in the Tafsīr al-Tahrīir wa al-Tanwīr. He was good

${ }^{1}$ Sumanto AlQurtuby, "Catholics, Muslims, and Global Politics in Southeast Asia," Al-Jami'ah: Journal of Islamic Studies 50, no. 2 (December 27, 2012): 395.

2 Bassām Ridwān 'Ulyān, "Manhaj ibn 'Āshūr fī al-Qirā'āt fī-Tafsīrih alTaḥrīr wa al-Tanwīr," Majallat al-Jāmi'ah al-Islāmīyah (Silsilat al-Dirāsāt alIslāmīyah) al-Mujallad al-Tāsi' 'Ashr, al-'Adad al-Thāni (June 2011): 545-573.

3 Abdul Aziz Muchammad, "Shari’ah dan Tafsir Qur'an: Elaborasi Maqā șid dalam Tafsir Ibn 'Ashūr" (The sis Post-graduate, Universitas Islam Negeri Syarif Hidayatullah, 2008), 7, 38.

${ }^{4}$ Muhạmmad Riḍā al-Ajhūrī, al-Khalfiyyah al-Islāmīyah li-Majallat al-Aḥwāl alShakhșìyah (Tunis: al-Shirkah al-Tunisiyah li al-Nashr wa al-Tanmìyah, 2012), 133-134. 
enough to explain about the social and political life in Tunisia when Ibn 'Âshūr was involved in it. ${ }^{5}$ In his research on ibn 'Āshūr, Musolli concluded that in the interpretation of ibn' Āshūr, al-'Ibrah bi-Idiūlüjūyah is more dominant than al-'Ibrah bi khușuss al-Sabab in the sense that Quranic interpretation is often built to reinforce the ideology of an interpreter himself. But this research has not touched on how a work of interpretation has fallen on identity politics in relation to the ideology of the interpreter. ${ }^{6}$ Abu ụassān in his research wrote a biography of Ibn 'Āshūr. ${ }^{7} \mathrm{He}$ discussed allegations of inconsistency of Ibn 'Āshūr in addressing the legal decrees determined by the rulers or governments of his day. However, Abū Hassān has not revealed the politicized part of the interpretation and the law-based political identity of Ibn 'Āshūr.

Ainur Rofiq concluded that the Qur'an is a holy book of Muslims that contains the nature of rahmatan li al-'ālamin its interpretation should not be contradictory and violating human rights, and destroying the religious and ecological shrines. Although he describes the terminology of interpretation of the Qur'an's attention to the question of the peace of harmony, his work does not entail the interpretive nuances of identity politics dominated by a particular ideology. ${ }^{8}$ Ahmad Suaedy, in Politicization of Religion and Communal Conflict, explains that freedom of expression does not always provide assurance to someone to realize mutual appreciation and respect. This book reveals various consequences of religious politicization that cause communal conflict among fellow believers both internally and externally. ${ }^{9}$

${ }^{5}$ Kamel Ghozzi, "The Study of Resilience and Decay in Ulema Groups: Tunisia and Iran as an Example," Sociology of Religion 63, no. 3 (October 1, 2002): 362.

${ }^{6}$ Musolli, “Hegemoni Ideologi dalam Penafsiran Qur'an; Studi Tafsir Syiah dan Tafsir Sunni al-Tahrīr wa al-Tanwīr" (Dissertation, Universitas Islam Negeri Syarif Hidaya tullah, 2014), 257.

7 Jamāl Maḥmūd Aḥmad Abū Ḥassan, "al-Imām Muḥammad al-Ṭāhir ibn 'Āshūr (Sìrah wa Mawāqif)', 66.

${ }^{8}$ Ainur Rofiq, Tafsir Resolusi Konflik (Malang: UIN Maliki Press, 2011), 267268.

${ }_{9}$ Ahmad Suaedy, Politisasi Agama dan Konflik Komunal: Beberapa Isu Penting di Indonesia (Jakarta: Wahid Institute, 2007), 356. 
Drawing on the aforementioned literature, there remains a dearth of research that specifically discusses the view of Ibn 'Āshūr regarding the role of the minority in a nation. In the context of Tunisia, themes about relations between Muslims and nonMuslims have at least been discussed by Khayr al-Dīn al-Tūnisī (w.1890) and 'Abd al-'Azīz al-Tha'âlibī (w.1944) who discussed an open attitude to cooperation with non-Muslims. Khayr al-Dīn wrote the book Aqwām al-Masālik fī-Ma'rifah Ahwwāl al-Mamālik. In this book, he suggested that the need for the Tunisian state to establish cooperation with non-Muslims, which in this case is with European countries such as France. He also criticized the 'ulamas (scholars) whom he considered to be resistant to something derived from non-Muslims. ${ }^{10}$ In line with al-Tha'âlibi through his work Rüh al-Taharrur fi al-Qur'ān, reminiscent of the importance of building cooperation with non-Muslims with the approach that non-Muslim are also humans (al-taqārub bayna al-bashar). He criticized a number of interpretations that prohibit Muslim to have a relation with non-Muslims, such as visiting their country, cooperating in trade with them and so on. ${ }^{11}$

Ibn 'Āshūr's interpretation of Muslim relations with nonMuslim shows a totally opposite attitude to his predecessor Khayr al-Dīn and al-Tha'ālibi. Ibn 'Āshūr denoted his rejection of nonMuslims and negated their contribution to the development of Tunisia as a predominantly Muslim country.

This paper mainly aims to present the interpretation of ibn 'Ashūr in Tafsìr al-Taḩrīr wa al-Tanwwìri2 about shūrā

10 Khayr al-Dīn al-Tūnis̄i, Aqwām al-Masālik fī Ma'rifah Ahwō̄l al-Mamālik (Tunis: al-Dār al-'Arabiyyah li al-Kitāb, 2012), 62-67.

11 'Abd al-'Azìz al-Tha'ālibī, Rūh al-Taharrur fi al-Qur'ān (Tunis: Dār al-Gharb al-Islāmī, 1985), 33-41.

12 Before the interpretation of ibn Āshūr was recorded, a number of his writings on interpretation were published in Al-Majallah al-Zaytūnah which is the academic journal of al-Zaytun University, which was first published in 1936. In this year he wrote only about the science of interpretation, then in 1937 then he began to write a commentary on the sura al-Fātihah. "Hay'at min Mudarrisī Jāmi' al-Zaytūna al-Ma'mūr," Al-Majallah al-Zaytūnah, October 1937, 5; Before writing his interpretation, ibn "Āshūr has long interpreted the Quran through religious speeches in Jāmi" Zaytūna since 1920. Before being codified into a full interpre tation, his interpre tations have been published periodically in Majallat al- 
(deliberation/consultation) and alms and the involvement of nonMuslim citizens in them. The interpreted verses are Surah Âli 'Imrān (3): 159 and Surah al-Baqarah (2): 264. Other interpretations are also discussed in this paper in order to provide a variety of interpretations from other interpreters. In so doing, this study adopts Malasevic's theory of identity politics which states that identity politics is not only exercised by marginalized people, or minority groups in the midst of a major power in a country, but also in the majority group, as well as within the group in power.

\section{Iden tity Politics}

Malasevic in his book Identity as Ideology stated that identity politics is not only exercised by marginalized people, or minority groups amids of majority and dominant group in a country, but it is also performed by the majority and even amongst the ruling group. Such hegemony occurs in the practice of religious, social, and political life. The identity politics model takes place in various forms, including politics of religious identity, identity of sects, schools of thought, ethnicity, group, race and gender. The empetus is the desire to get the right of political autonomy, justice, opportunity, equality, freedom, continuity of existence and to maintain the status quo, and to seek for support, protection, respect, recognition and justification of ideology. ${ }^{13}$

In a public order, the majority group tends to reinforce its identity. Politically, this group may exclude others who are inconsistent with them and the communities not accommodating the interests of other groups, especially in the matter of ideology and religious differences. They may even exclude others and call them infidel. This is common in the context of inter-religious and intra-religious relations.

Socially, identity politics can occur unplanned, but it often appears in the behavior of one's consciousness over the ideological

\footnotetext{
Zaytūna, an academic journal of the Zaytūna campus that published his first edition in 1935. Muhạmmad al-Ḥaddād, "Al-Khiṭāb Hawla Al-Mar'ah: Bayna AlMunāọil Wa Al-Shaykh Wa Al-Za'īm," Bāhithāt, al-Kitāb al-Tāsi' 16 (2004 2003), accessed December 29, 2014, www.bāhithāt.org/download.php?file_id=MzQ4.

13 Sinisa Malesevic, Identity as Ideology: Understanting Ethnicity and Nationalism (London: Palgrave Macmillan, 2008), 35.
} 
reflection they believe in. According to Shafi'i Ma'arif, those marginalized will engage in identity politics in any way for justice, and may even emerge as a radical group wearing an attire in the name of religion as an attempt to reach a goal. ${ }^{14}$

The question is what does the context of the interpretation of al-Taḥrìr wa al-Tanwīr by Țāhir Ibn 'Āshūr and its relation to identity politics? The authors will deal with how the ideological interpretation of $\mathrm{Ibn}$ 'Âshür with all the socio-political and institutional aspects affect his method of interpretation. If it is read from the perspective of identity politics theory, a work of interpretation will be yielded as a product of interpretation with the motive of the defense of the group (identity groups), both interreligiously and intra-religiously in its own right.

\section{Shūrā in the Interpretation of Ibn 'Āshūr}

When interpreting Surah Āli 'Imrān (3): 159,15 Ibn 'Āshūr stated that the deliberation or consultation should be conducted on all matters to achieve the good in the family, group, or among the ummah. According to him, what is discussed should be on issues that have not been established in the Quran and Sunna. They are part of the Shari'a that has been described by the Prophet Muhammad. ${ }^{16}$

He added that there are three criteria that must be met by a group when they want to carry out the deliberation. First, the deliberation should be held by the ulamas (scholars). Ulamas (scholars) are people who understand the precepts what is right to determine the position or law in a case. They decide based on views on the basis of the shar'i laws. Second, the deliberation should be shared with those who are concerned with the issue. In

14 Ahmad Syafi'i Ma'arif, "Politik Identitas dan Masa Depan Pluralisme Kita," in Politik Identitas dan Masa Depan Pluralisme Indonesia, ed. Ihsan Ali Fauzi (Jakarta: Democracy Project, 2012), 10.

15 Translation of the verse: "So by mercy from Allah, [O Muhammad], you were lenient with them. And if you had been rude [in speech] and harsh in heart, they would have disbanded from about you. So pardon them and askforgiveness for them and consult them in the matter. And when you have decided, then rely upon Allah. Indeed, Allah loves those who rely [upon Him]".

${ }^{16}$ Muhạmmad al-Ṭāhir Ibn 'Āshūr, al-Tahrīir wa al-Tanwìr, vol. 4 (Tunis: Dār Saḥnūn li al-Nashr wa al-Tawzī', 1997), 147. 
other words, the party to be consulted should be the persons who are deemed to be interested and will take stance with those who initiate the deliberation. ${ }^{17}$ Third, deliberation-based on dāmīr "hum" in the above verse only applies to fellow Muslims because deliberation (استشار) is essentially asking for help (استعان) from the delegates. Therefore, it is not appropriate for Muslims to seek for help from non-Muslims. ${ }^{18}$

Table 1

\begin{tabular}{|l|l|l|}
\hline \multicolumn{3}{|c|}{ Interpretation of Ibn 'Āshūr on shūrā in the Qur'an } \\
\hline $\begin{array}{l}\text { Its members are } \\
\text { scholars }\end{array}$ & $\begin{array}{l}\text { The included scholars are } \\
\text { those who have the vision of } \\
\text { building the ummah }\end{array}$ & $\begin{array}{l}\text { Shürantribution is } \\
\text { limited to the interests } \\
\text { of Muslims only }\end{array}$ \\
\hline
\end{tabular}

The above criteria provide some important insights, namely Ibn 'Âshūr in this case views the position of deliberation only at the level of fellow Muslims. ${ }^{19}$ He negates the role of non-Muslims on it because of the impossibility of non-Muslims dealing with the matters for the benefits of Muslims.

Table 2

\begin{tabular}{|l|l|l|}
\hline \multicolumn{3}{|c|}{ Rejection of non-Muslims' involvement in Shürā } \\
\hline $\begin{array}{l}\text { Non-Muslims are not on } \\
\text { the side of the common }\end{array}$ & $\begin{array}{l}\text { Non-Muslims are not } \\
\text { equal to Muslims }\end{array}$ & $\begin{array}{l}\text { Non-Muslims cannot } \\
\text { specifically fight for the }\end{array}$ \\
\hline
\end{tabular}

${ }^{17}$ Muhạmmad al-Ṭāhir Ibn 'Āshūr, al-Tahrīir wa al-Tanwīir, vol. 25 (Tunis: Dār Saḥnūn li al-Nashr wa al-Tawzī', 1997), 112.

${ }^{18}$ Ibid.

${ }_{19}$ The textual proselytization of Ibn Âshūr is visible among them from his point of view and his critique of the book of al-Islām wa Uṣūl al-Hukm by Āli Abd al-Rāziq. Abd al-Rāziq holds the main view that caliphate type of government cannot be called a political system. This issue sparked the polemics among many scholars at that time, including Ibn Āshūr who made strong criticism by writing a book to refute the book written by Abd al-Rāziq. In conclusion, Ibn Āshūr stated that the caliphate is a real political system, easily understood by nas that mentions the word in the Quran. Meanwhile, in the view of Abd al-Rāziq, the text used in no way implies the obligation of the establishment of the caliphate, and cannot be decla red ijma' be cause the re a re still scholars who do not agree to establish a khilāfah. See 'Ali 'Abd al-Rāziq, al-Islām wa Ușul al-Hukm (Beirut: Dār Maktabah al-Ḥayāt, n.d.), 38; Muḥammad al-Ṭāhir Ibn 'Āshūr, Naqdun 'Ilmīyyun li Kitāb al-Islām wa Ușūl al-Hukm (Cairo: Dār alSalām, 2014), 60-61. 
Ibn 'Āshūr puts the role of scholars very dominant in deliberations. In his political view, scholars cannot be separated from politics. This is because the view of the ability of scholars in understanding the theorems of Shari'a has a very important position in solving a problem of government and state. The existence of scholars becomes very important in defending and advocating the upholding of Islamic laws. Establishment of the concept of chaliphate is the only way in implementing Islamic law as a whole. The paradigm of the Islamic state seems to be confirmed by the strategic role of scholars in deliberation.

Ibn 'Āshūr extended his view on the issue of deliberation. Deliberation is a forum that brings together various elements of society, not just religious leaders. Citing the opinion of the Maliki school of thought, that deliberation is of paramount importance, and that the law is obligatory. In some Maliki figh literature, the author finds the beginning of discussion with the importance of deliberation. Prophet Muhammad, for example, always held deliberations with many of his companions in accordance with their capacities in various fields, as long as it was not related to the establishment of Shari'a ( $\left.\operatorname{tash} r_{\bar{i}}{ }^{\prime}\right)$. In the context of the state leaders (waliy al-amr), they are obliged to consult with scholars for problems that cannot be solved, ranging from problems on religious matters, scripture understanding, to the benefit and improvement of the quality of the population or to the state. This makes a formulation of rules in the Malik School of thought as follows:

$$
\text { الشُّورى من قوَاعد الدِّين وعزائم الأحكام ومن لم يستشر أهل العلم والدين فعزْله واجبُ.20 }
$$

A deliberation is held by dividing up the topics of the problem and discussing them with relevant experts. For example, in respect to religious matters, the deliberation is held together with scholars. The topics and strategies of war are discussed with the military. Certain topics are discussed in accordance with interested parties,

${ }^{20}$ Muha mmad al-Amīr al-Kabīr, al-Iklīl Sharh Mukhtaṣar Khalīl, vol. 3 (Beirut: Dār al-Fikr, 1989), 245. 
perhaps from employees, ministers, and workers. The whole is related to the benefit and the realization of a civilized country. ${ }^{21}$

When discussing the deliberations in the context of the state, Ibn 'Âshūr still does not include consultation with non-Muslims as part of this verse due to the absence of the political inequality between Muslims and non-Muslims. ${ }^{22}$ This view is related to the attitude of protection of Islam in constitution and the Shari'a which is not negotiable. Ibn 'Āshūr puts non-Muslims out of alignment with Muslims even though this understanding has the potential of a "conflict of sentiment" among religions.

\section{Asbab al-Nuzul of the Verses}

On the perspective of $a s b \bar{a} b$ al-nuz $\bar{u} l$, the verses about shūra are a series of public attitudes of the Ansār companion. The deliberation is an inseparable part of their culture, whether before embracing Islam or after. That is, deliberation has become the tradition of Anșār society, not something new born along with the presence of Islam to the city of Medina. In other words, it is not appropriate to question the identity of religion in seeking for solutions to social problems that are expected to be resolved by deliberation. The barriers constructed by Ibn 'Āshūr in the context of deliberation between Muslims and non-Muslims are more on the grounds of protection of the existence of Islam.

This verse, according to Ibn 'Āshūr, is sent down for the Anșār community, namely those who accepted Islam from the city of Medina. Deliberation is a habit that cannot be separated from the people of Medina. They are often deliberative in all matters relating to the welfare of the community. The most interesting deliberation --and Allah praises them with the revelation of this verse-- is a deliberation performed with representatives of Anșār who embraced Islam in Bai'at al-Aqabah. The Representatives of the Anșār discussed and conveyed to the Anșār community regarding the conversations they had with Prophet Muhammad. After

${ }^{21}$ Ibn 'Āshūr, al-Tahrīir wa al-Tanwīr, 4:148.

${ }^{22}$ Muhạmmad al-Ṭāhir al-Mīsa wī, Jamharat Maqālāt wa Rasāil Shaykh al-Imām Muhammad al-Ṭāhir Ibn 'Āshūr, vol. 2 (Amman: Dār al-Nafāis li al-Nashr wa Tawzī, 2015), 718. 
hearing from the representatives of the Anșār, the community agreed to gather in the house of Abū Ayyūb al-Anșāri to embrace Islam and always defended Prophet Muhammad. ${ }^{23}$

In the discussion of the Qur'an in surah Âli 'Imrān (3): 159, among the prerequisites of the deliberation is the similarity between those who initiate the deliberation and those invited. This is supported by the verse of wa amruhum shūrā baynahum. Ibn 'Āshūr understands the expression baynahum in the verse that is those who are concerned with the same problem. It should not be deliberated with outsiders. In the view of Ibn 'Āshūr, Islam must reject unity and cooperation with non-Muslims, as affirmed in Ușūl al-Nizām al-Ijtimā'i. According to him, Islam calls on humanity to unite because after all, this religion is a religion of fitrah and Allah has shown various sides of beauty and its virtue. However, Islam does not instruct us to unite with those who refuse it because they are choosing a path of less value in the eyes of Allah. ${ }^{24}$ This is in line with the guidance of surah Āli 'Imrān (3): 19.

\section{Non-Muslims and Politics in the Context of the State of Tunisia}

In the context of Tunisia, religions other than Islam do not have a wide opportunity to participate in socio-political activities. However, to boost its economy, this country is highly dependent on tourists coming from non-Muslim majority countries. Indonesian Ambassador to Tunisia, Ronny P. Yuliantoro, stated that until now Tunisia still needs non-Tunisian residents who are mostly non-Muslims to meet their foreign needs.

In Tunisia, non-Muslim political space is limited. Ibn 'Āshūr also supports this point of view, though not necessarily entirely erroneous. This is because the majority of the people of Tūnisia are

${ }^{23}$ Ibn 'Āshūr, al-Tahrīr wa al-Tanwīr, 25:111. In comparison, in this part Ibn 'Āshūr quotes exactly what al-Qurțūbī says in the interpre tation of this verse. See Abū 'Abdullūh Shams al-Dīn Muhammad ibn Aḥmad ibn Abī Bakr ibn Farḥ alAnșārī al-Khazraj̄̄i al-Qurțūbī, al-Jāmi' li Aḥkām al-Qur'ān, vol. 16 (Cairo: Dār alKutub al-Mișrīyyah, 1964), 37.

${ }^{24}$ Muḥammad al-Ṭāhir Ibn 'Āshūr, Ușūl al-Niz̄ām al-Ijtimā'i fi al-Islām (Tunis: Dār al-Salām/Dār al-Saḥnūn li al-Nashr wa al-Tawzī', 2010), 217. 
$99 \%$ Sunni Muslims, ${ }^{25}$ and the rest is a mix of Shiites, Baha'is, Jews, and Christians. He excludes Shi' is from the mainstream Islam of Sunni.

\section{Ibn Āshūr's Resistance to Non-Muslims}

Ibn 'Āshūr's rejection to the involvement of non-muslim parties in the deliberation is as an effort to protect the interests of Islam and Muslim society. This seems to be the political orientation of Ibn 'Āshūr in the state enforcement with the concept of caliphate. Yet -as Abdullah Ahmed an-Na'im says- the paradigm simply follows the regime system of the past (classical thinking), such as the Fātimìyah who had ruled Tūnisia in North Africa since 909. The classical thought em phasizes that the concept of unification of the state leadership with religion is a package that cannot be dismantled. ${ }^{26}$ The concept of caliphate often prioritizes the Islamic identity, rendering non-Muslims ineligible to be leaders in an Islamic state or Muslim country.

Efforts to save Islamic principles through the Shari'a constitute Ibn 'Âshūr's priority. In his view, if non-Muslims are freely involved in deliberation, it is feared to disrupt the stability and interests of Muslims because only the latter recognize their own interest. On the contrary, non-Muslims will not take into consideration the interest of their Muslim counterparts. The efforts of maintaining the continuity of Islamic existence can be safeguarded if non-Muslims are excluded from deliberations, where all matters related to religious and state policy are inseparably addressed.

Ibn 'Āshūr's attitudes which do not accommodate nonMuslims in deliberations are not only related to the substance of Islamic identity protection, but also related to the substance of the deliberation itself in relation to the law and the enforcement of the rule of law. Moreover, in the Constitution of the State of Tünisia, it is written that Tünisia is an independent state of sovereignty;

25 “Tunisia Demographics Profile," accessed November 12, 2016, https://www.indexmundi.com/tunisia/demographics_profile.html.

26 Abdullah Ahmed al-Na'îm, Islam dan Negara Sekuler: Menegoisasi Masa Depan Syariah, trans. Sri Murniati (Jakarta: Mizan Pustaka, 2007), 109. 
Islam is the official religion of the state; its official language is Arabic; and the system of governmenance is the Republic.

$$
\text { "تونس دولة حرّة مستقلَّة ذات سيادة الإسلام دينها والعربية لغنها والجمهرية نظاما27" }
$$

Here we see that Ibn 'Āshūr's interpretation is ideological. According to him, if non-Muslims are included in deliberations, discussing the law or constitution of the state, this will be a threat to the enforcement of Islamic law in the state. Therefore, nonMuslims' participation should be limited strictly. This can only be done by eliminating their role in deliberations.

According to Cressida Heyes's theory, identity politics is reflected in the efforts of a particular ethnicity (both religious and social) to incorporate the values of ethnicity into the state legislation. In the religious context, the politics of identity is evident in the diversity of a particular 'splinter' religious community to include religious norms and values in policymaking processes, or laws, including the desire to enforce Islamic law based on the understanding of the salaf generation, or the application of the concept of caliphate as a system of government. ${ }^{28}$

Ibn 'Āshūr's view of non-Muslim exclusion in the deliberation forum is a form of distrust and suspicion to non-Muslims. This view of Ibn 'Āshūr is based on a prejudiced tendency, or zann in the interpretation of scriptural texts, as the term Toshihiko Izutsu refers to it. It may be that Ibn 'Āshūr is influenced by the impetus of justification for his ideology. In a stricter manner than that, Toshihiko calls it with a presumption that comes from al-hawā or lust, ${ }^{29}$ not purely divine. In the context of identity politics, such interpretation of the Quran can be categorized as entrapment into identity politics.

${ }_{27}$ Tūnisiyyah, Dustūr al-Jumhurīyyah al-Tūnisiyyah (Tunis: Majma' al-Aṭrāsh li al-Kitāb al-Mukhtaṣ, 2014), 5.

${ }^{28}$ Ma'arif, "Politik Identitas dan Masa Depan Pluralisme Kita," 3.

29 Toshihiko Izutsu, God and Man in The Qur'an (Kuala Lumpur, Malaysia: Islamic Book Trust, 2002), 57-58. 


\section{Contribution of $A h l a l-K i t a \bar{b}$ to Infrastructure Development}

In fact, the term contribution of Ahl al-Kitab to infrastructure development is never mentioned in Ibn 'Âshūr's intepretation. However, according to our view, although Ibn 'Āshūr only interprets the verses about alms-giving, it does not mean that this cannot be interpreted as the Ahl al-Kitab's contribution to infrastructure development because in practice Ibn Âshūr never refuses to accept aid from non-Muslims for the construction of mosques.

In interpreting Surah al-Baqarah (2): 264, ${ }^{30} \mathrm{Ibn}$ 'Āshūr mentions that the charity from the unbelievers is worth nothing, because it is categorized as al-mann wa al-azāa. In this verse, it is mentioned that people who do not believe in Allah and the Last Day (hence they are called infidels) among the sign of their behavior is mentioning the charity they have given. The phrase almann wa al-azā is a description of the expression that hurts the listener when spoken. Al-mann wa al-az̄a mean mentioning one's gift to the point that the giver is a better person than the one given, for them the receiver is the poor. ${ }^{31}$

Why are the people who mention their charity in this verse the same as those who do not believe in Allah and the Hereafter? Ibn 'Āshūr gives an explanation that the one who is proud of giving is certain to forget that Allah gives him the ability to give charity

${ }^{30} \mathrm{O}$ you who have believed, do not invalidate your charities with reminders or injury as does one who spends his wealth [only] to be seen by the people and does not believe in Allah and the Last Day. His example is like that of a [large] smooth stone upon which is dust and is hit by a downpour that leaves it bare. They are unable [to keep] anything of what they have earned. And Allah does not guide the disbelieving people.

${ }^{31}$ Quoted al-Ghazālī in Iḥyā "Ulūm al-Dīn, that the al-mann attitude is an attitude that is already embedded in the human heart. This attitude follows part of the conditions and traits that a re often attached to the human heart. Then, the attitude of the heart develops into the behavior contained in speech and action, including the attitude of the adhā". Attitudes arise through two things, the reluctance of the giver to give a way his we alth because he is very eager to have it, and his attitude that sees himself richer and the one being given is the poor. See, Abū Ḥāmid Muhammad ibn Muhammad al-Ghazālī, Iḥyā' 'Ulūm Al-Dìn, vol. 1 (Beirut: Dār al-Ma'ārif, t.th.), 216; Muḥa mmad al-Ṭāhir Ibn 'Āshūr, al-Tahrìr wa alTanwīr, vol. 3 (Tunis: Dār Sa ḥnūn li al-Nashr wa al-Tawzī', 1997), 46. 
which will reward him in the Hereafter. At this stage, the same person as the unbelievers is equally unconvinced that Allah has given them the ability to give charity. ${ }^{32}$

Ibn 'Āshūr looks so cautious in the view of the status of deeds committed by non-Muslims. Furthermore, he says that anything done by non-Muslims has no benefit whatsoever. ${ }^{33}$ This notion suggests that Ibn 'Āshūr does not provide a gap between Muslim and non-Muslim cooperation, including in muamalah and state affairs, including in infrastructure development.

As mentioned above, Ibn 'Āshūr argues that all good works of non-Muslims will not be accepted, because they do not want to believe in Allah and the Last Day. In this verse too, almsgiving is synonymous to the soil exposed to rain, so it is worth nothing. This interpretation provides an illustration that a theological view is used in order to show the identity of the majority. As widely known, the Tunisian community has always been almost $99 \%$ Muslim. Among their social interaction with non-Muslims was when the entry of French occupation into Tunisia in the late 19th century. At this time, the Tunisia's economy was desperately bad that the Bay government (Tunisia's Ruler of Turkey) sided with France, so Tunisia was called the French Protectorate (al-himāyah al-Faransìyyah).

Imam al-Tabari in his interpretation states that the invalidity of the non-Muslim alms before Allah is contained in several narrations. There is a narration, for example, which states:

$$
\begin{aligned}
& \text { وهذا مثل ضربه الله لأعمال الكافربين يوم القيامة يقول: لا يقدرون على شيء مُّا كسبُوا يونئذِ كنا } \\
& \text { ترك هذا المطر الصفا نقِيَّ لا شيءَ عليه. }
\end{aligned}
$$

This narration is a parable provided by Allah of the unbelievers before Him on the Day of Resurrection. They do not get results from what they did in the world. It is illustrated as a continuous rain in summer, but it has no effect. ${ }^{34}$

Al-Ḍaḥāak, an interpreter from among the tabiins also quoted by al-Tabarī, states that the person who does not invest his

32 Ibn 'Āshūr, al-Tahrīr wa al-Tanwīr, 3:48.

${ }^{33}$ Ibid., 3:50.

${ }^{34}$ İmām Abū Ja'far Muhạmmad ibn Jarīr ibn Yazīd al-Ṭabarī, Jāmi" al-Bayānfi Ta"wōl ay al-Qur'ān, vol. 3 (Beirut: Dār al-Kutub al-'Ilmiyyah, 1999), 66-67. 
property is even better than the infidel but accompanied by the nature of ria and denouncing the alms he has given (al-mann wa al$a z \bar{a})$. It is likened to an infidel who gives charity but does not believe in Allah and the Last Day. ${ }^{35}$ Therefore, what they give is of no value, and the reward is lost in the sight of Allah. The same is said by al-Bayḍawi in his commentary. According to him, being proud by mentioning what one has given is among the characteristics of people who do not believe in Allah who should be shunned. ${ }^{36}$

Al-Sha'rāwī also does not place the interpretation of this verse in the context of judging the alms of non-Muslims. This verse is positioned as a reprimand to those who do not use ethics when giving away his property. At least, the person gets two losses at once, i.e. his property is reduced because his wealth will not be added by Allah, and what has been given will not be rewarded by Allah. Therefore, al-Sha'rāwī criticizes people who give charity with jargon in order to "increase his sustenance". According to him, gift to others may not always be rewarded in the world, but later in the hereafter. ${ }^{37}$

Al-Ṭabătabā'î puts this verse in the topic of the properties of the hypocrites. He gives a basic idea that the person who presents the sense of hope and mentions alms after doing it basically has disbelieving qualities in it. However, the person who does this does not mean he does not believe in Allah. The person who does this is the one who does not believe that the commission to give alms will be rewarded before Allah if done with all his heart. This is the state of a charity of person not with the aim of obtaining the pleasure of Allah. ${ }^{38}$

Indonesian interpreter, Hamka, also express similar views. This illustration is also used for people who mention or bring up their own good deeds, to hurt people who have felt their kindness, which is the same as the behavior of the unbelievers. The point of the similarity is the theological belief that what non-Muslims do -

${ }^{35}$ Ibid., 3:67.

36 'Abd Allah Ibn 'Umar Ibn Muḥammad al-Shīrāzī al-Bayḍā wi al-Shāfi'i, Anwār al-Tanzìl wa Asrār al-Ta'wīl, 1/158.

${ }^{37}$ Muha mmad Muta wallī al-Sha'rā wī, Tafsìr al-Sha' rāwō̄, 2/1168-1169.

${ }^{38}$ Muha mmad Ḥusayn al-Ṭabāṭabā'ì, al-Mīzān fī Tafsìr al-Qur'ān, 2/392-393. 
despite being good-has no value before Allah because they deny Allah as God by associating or believing in another God and denying Muhammad's prophethood as His messenger. ${ }^{39}$

The alms which Ibn 'Âshūr understands in the interpretation of al-Baqarah (2): 264 in relation to the alms of non-Muslims is judged as al-mann wa al-adha, and it is because of their infidelity. The articulation of a religious group beyond Islam into a pagan group results in the denial of the existence of the alms they are giving. The sentence of al-mann wa al-adhā means insincerity, there are certain intentions implied behind the alms. This is a result of the notion of concrete terms of the terminology of religion and infidelity and certainly non-metaphysical, ${ }^{40}$ thus giving birth to sectarian boundaries that prevent non-Muslims from getting a place in alms-giving.

As described by Muhammad Bouzguiba, Ibn 'Āshūr was asked to issue a fatwa on donations for the construction of a mosque from a non-Muslim group in this case those of the French protectorate group at the time. Ibn Âshūr replied that he could not issue the fatwa, because the law cannot be called a mosque that does not meet the laws of the mosque to be practiced in it congregational prayer and so on. ${ }^{41}$

The interpretations that form the basis of the ideology of some of his readers are consciously derived from the results of sectarian ideological beliefs. ${ }^{42}$ According to Amin Abdullah, it is said to be sectarian-ideological. This will lead to the attitude of directing others to follow his belief, even to the radical level. Such a group

${ }^{39}$ Abdul Malik Karim Amrullah,Tafsir al-Azhar, 1/532-533.

40 Ahmad Suaedy, et.al., Dialog: Kritik dan Identitas Agama (Yogyakarta: Pustaka Pelajar, 1994), 70-71.

${ }^{41}$ Muḥammad Bouzguiba, Fatāwāa al-Shaykh al-Al-Ṭāhir Ibn 'Āshūr (Tunis: alDār al-Tūnisīyyah li al-Nashr, 2015), 337.

${ }^{42}$ When studied profoundly, the debate about who is called Ahl al-Kitāb is still debatable. Zainun Kamal for example argues that Ahl al-Kitāb is an elastic and flexible term, in the sense of not being limited only in the sphere of Judaism and Christianity. Both a re called Ahl al-Kitāb because there is a classification of the division of religion into the religion of samāwi and ardì . In fact, all religions claim their holy book as the revelation of God (samāwi). More can be found at: http://islamlib.com/agama/minoritas/zainun-kamal-penganut-budha-dan-hinduadalah-ahlul-kitab/. Accessed on: 16 November 2016, 16:19. 
according to Musdah Mulia, tends to reinforce its identity and community, even in the final stage, it will degrade and marginalize the belief of others. ${ }^{43}$ In terms of interpretation, this will lead to a closed attitude to the opinions and interpretations of others, assuming the interpretation to be more correct. All of which leads to the attitude of identity politics whether done consciously or not.

Charfi underlines that there is in fact no significant contestation between religions in Tünisia, either from the time of the French protectorate or the present. The contemporary geneology of contestation is about the struggle between conservative and liberal groups. This can be seen from the emergence of the strong refutation of the hard-line Zaytünah scholars against the modernization mission promoted by President Bourguiba through Ibn 'Āshūr through the campaign of Iṣlāh alTa'lìm al-Zaytūnī (Zaytūnah Educational Reform). The campaign was responded negatively by Zaytūnah scholars, assuming that it was a Westernization effort made on Zaytūnah. ${ }^{44}$ The struggle between the liberal-conservative groups in Tunisia is still occurring to this day, especially in the case of Majallat al-Ahwāl alShakhsìyyah voiced by society through the Tunisia parliament.

The issue of non-Muslim leadership is not very worrying for Tunisia. This is because, according to a recent survey of 2016, the number of non-Muslim residents in this country is no more than $1 \% .{ }^{45}$ Therefore, the prohibition of election of non-Muslim leaders is something that is not very substantive in the country, because Muslims are the majority. In terms of acceptability alone, it is certain that Muslims will lead Tunisia. Al-Ajhūri also criticizes Ibn $\bar{A}$ shūr's views on the appointment of non-Muslim leaders, that the condition is unsuitable if the country is at peace and Muslims and non-Muslims live side by side. ${ }^{46}$

${ }^{43}$ Musdah Mulia, "Politik Identitas: Ancaman Terhadap Masa Depan Pluralisme di Indonesia," in Politik Identitas dan Masa Depan Pluralisme Indonesia, ed. Ihsan Ali Fauzi (Jakarta: Democracy Project, 2012), 48.

44 Personal interview with Abdul Majid Charfi, in his office, Tūnis, 14 December 2015, at 02:15 p.m.

45 "Tunisia Demographics Profile."

${ }^{46}$ Personal intervie w with Riḍa al-Ajhūri, 3 November 2015, at 10:53 a.m. 
Regarding Muslim-non-Muslim relations, Khayr al-Dīn alTūnīsì has stated that we must be inclusive in interacting and thinking in this day and age. We should not imagine that this world is only inhabited by a single nation, but there are many nations in the world with a diversity of different needs, interests and abilities. Meanwhile, everyone wants their universal needs fulfilled in ways that can specifically meet their needs. ${ }^{47}$

Ibn 'Āshūr is assertive toward non-Muslims, as this is clearly expressed in his writings, for example in his book entitled Ușūl alNiz̄a $m$ al-Ijtma' $i$. Islam does tell the human race to unite because Islam is the religion of nature that Allah has shown the sides of its virtue. However, Islam does not enjoin its followers to unite with those who reject the truth of the religion because they have chosen something lower in the eyes of Allah. ${ }^{48}$ This attitude is in response to the attitude of non-Muslim rejection of Islam itself, as an effort to maintain the dignity of Islam so as not to be underestimated by those who reject it.

Ibn 'Āshūr's exclusiveness toward non-Muslims is made in order to protect the Islamic Shari'a in the Tunisian society. However, his argument creates a distance between Muslims and non-Muslims. This is in contrast to Mounchef Chenoufi, who examines the ideas of Khayr al-Dīn al-Tūnisy. He encourages Muslims to brave the rigors of mainstream religious thought of the past and dare to be open to others, including different religions. Even if they are different from us, it does not prevent us from imitating the good things of those who are associated with worldly good. This is similar to the Europeans who want to imitate Islam which is considered to bring the benefit for them to become Europe that we see today. ${ }^{49}$

According to Syafi'i Ma'arif, there is a correlation between life experiences and the context of life that surrounds a person with a loose attitude or at least someone in interpreting the teachings of Islam. Those who do not often associate with, and take distance themselves from, non-Muslims, and never living in a

${ }^{47}$ al-Tūnisī, Aqwām al-Masālik fì Ma'rifah, 102.

${ }^{48}$ Ibn 'Āshūr, Ușūl al-Niz̄ām al-Ijtimā'i fi al-Islām, 216-217.

${ }^{49}$ Monchef Chenoufi, al-Muqaddimah wa Taqāriz al-Mu'āṣirīn "ala al-Masālik Fì Ma"rifati Ahwwāl al-Mamālik (Tunis: al-Dār al-'Arabiyyah li al-Kitāb, 2012), 64. 
predominantly non-Muslim country, are usually more conservative and rigid. Meanwhile, those who are educated with various professions who are able to compete with the majority population in non-Muslim countries are usually more lenient in interpreting religious teachings. This is because they already feel part of the mainstream society with all the dynamic of its plurality. ${ }^{50}$

Ibn 'Āshūr's emphasizes literal meaning in understing of the texts. This places him as a scholar who performs interpretations employing a linguistic approach. Because the Quran is revealed in Arabic, the construction of the Arab culture is linguistically inseparable from his understanding of the Quran itself. Apparently, Ibn 'Āshūr sees interpretation as something sacred. Although the Qur'an is revealed to all mankind, he reads it in the perspective of the benefit of Muslims only.

\section{Conclusion}

Ibn 'Āshūr's view on the Quran, especially on the involvement of non-Muslims in deliberation and contribution, shows that he is very cautious about non-Muslims' participation in a Muslim country. His Quranic interpretation may limit interreligious relation. His perception in relation to interreligious relations reveals that it is so difficult to build a state through interfaith union. In Ibn 'Āshūr's interpretation, the Muslim state affairs that should be open to participation from its citizens is narrowed to Muslims alone without the involvement of non-Muslims. They are not allowed to enter into the formulation of the state policies or the development of state infrastructure.

This can be understood from Ibn 'Āshūr's interpretation. He argues in al-Tahrīirwa al-Tanwwìr that deliberation (shürāa) as it is laid down in the Qur'an can only be done by scholars, who have the vision of building the ummah. He is also of the opinion that shürā is particulary set only for the interests of the Muslim Ummah. Therefore, non-Muslims cannot be included in any from of deliberation due to several reasons. First, non-Muslims do not take sides in general toward the interests of Muslims; second, non-

${ }^{50}$ Ma'arif, "Politik Identitas dan Masa Depan Pluralisme Kita," 10-11. 
Muslims are not equal to Muslims; and third, non-Muslims are unlikely to fight for Islamic Shari'a.

Second, in interpreting Surah al-Baqarah (2): 264, Ibn 'Āshūr says that the disbelievers who give charity are of no value because their charity belongs to the category of alms containing al-mann wa al-adha . Therefore, those who give charity not expecting the pleasure of Allah are the same to the alms of the infidel because there is no value of $u k h r \bar{a} w \bar{\imath}$ in it.

Third, this paper supports Malasevic's theory of identity politics stating that identity politics is not only perpetrated by the marginalized people or minorities. The majority may also use the same tool of identity politics to negate the minority. The views of Ibn 'Âshūr on consolidation and contribution suggest that he uses religious identity as a political tool to exclude the roles of minorities in developing a Muslim country. His interpretation of the shüra concept in the Qur'an shows that he is an exclusive interpreter. His exclusiveness aimed at protecting Islamic identity in a Muslim majority country is exaggeration. Ibn 'Ashur's position especially when interpreting verses about shūra exclusively prioritizes the interests of the Islamic group over others, and of course, the implication is that it is difficult for him to trust nonMuslims in the context of shürā.

From the perspective of identity politics, Ibn 'Āshūr's interpretation about shüra shows that he cannot escape from sectarianism because he emphasizes a particular identity that is Muslims alone over otnher minorities within a society or country. It means that there is an importance of Islamic identity in the interpretation of the verses. The Qur'an itself surpasses sectarianism. Therefore, sectarian thought reduced in the interpretation of sh $\bar{u} r \bar{a}$ in the Qur'an will in fact narrow the scope of its universality, and should therefore be reinterpreted, as this is promoted by other scholars discussed above.

\section{References}

al-Ajhūrī, Muḥammad Riḍā. al-Khalfiyyah al-Islāmīyah li-Majallat alA hrwāl al-Shakhșìyah. Tunis: al-Shirkah al-Tunisiyah li al-Nashr wa al-Tanmīyah, 2012. 
Bouzguiba, Muḥammad. Fatāwā al-Shaykh al-Al-Tāhir Ibn 'Āshūr.

Tunis: al-Dār al-Tūnisīyyah li al-Nashr, 2015.

Chenoufi, Monchef. al-Muqaddimah wa Taqāriz al-Mu'āṣirīn "ala alMasālik Fì Ma"rifati Aḥwāl al-Mamālik. Tunis: al-Dār al'Arabiyyah li al-Kitāb, 2012.

al-Ghazālī, Abū Ḥāmid Muḥammad ibn Muḥammad. Iḥyā' 'Ulūm Al-Dìn. Vol. 1. Beirut: Dār al-Ma'ārif, t.th.

Ghozzi, Kamel. "The Study of Resilience and Decay in Ulema Groups: Tunisia and Iran as an Example." Sociology of Religion 63, no. 3 (October 1, 2002): 317-334.

Haddād, Muhammad al-. "Al-Khițāb Hawla Al-Mar'ah: Bayna AlMunāọịl Wa Al-Shaykh Wa Al-Za'īm." Bāḥithāt, al-Kitāb alTāsi' 16 (2004 2003). Accessed December 29, 2014. www.bāhithāt.org/download.php?file_id=MzQ4.

Ibn 'Āshūr, Muhammad al-Ṭāhir. al-Tahrīir wa al-Tanwìr. Vol. 4.

Tunis: Dār Saḥnūn li al-Nashr wa al-Tawzī', 1997.

- - . al-Taḥrīr wa al-Tanwīr. Vol. 25. Tunis: Dār Saḥnūn li alNashr wa al-Tawzì', 1997.

- - - al-Tahrīir wa al-Tanwīrr. Vol. 3. Tunis: Dār Saḥnūn li al-Nashr wa al-Tawzì', 1997.

- - - Naqdun 'Ilmìyyun li Kitābal-Islām wa Ușūl al-Hukm. Cairo: Dār al-Salām, 2014.

- - - Ușūl al-Nizām al-Ijtimā'i fi al-Islām. Tunis: Dār al-Salām/Dār al-Saḥnūn li al-Nashr wa al-Tawzī', 2010.

al-Na'îm, Abdullah Ahmed. Islam dan Negara Sekuler: Menegoisasi

Masa Depan Syariah. Translated by Sri Murniati. Jakarta: Mizan Pustaka, 2007.

Izutsu, Toshihiko. God and Man in The Qur'an. Kuala Lumpur, Malaysia: Islamic Book Trust, 2002.

al-Kabīr, Muhammad al-Amīr. al-Iklīl Sharh Mukhtaṣar Khalīl. Vol.

3. Beirut: Dār al-Fikr, 1989.

Ma'arif, Ahmad Syafi'i. "Politik Identitas dan Masa Depan Pluralisme Kita." In Politik Identitas dan Masa Depan Pluralisme Indonesia, edited by Ihsan Ali Fauzi. Jakarta: Democracy Project, 2012.

Malesevic, Sinisa. Identity as Ideology: Understanting Ethnicity and Nationalism. London: Palgrave Macmillan, 2008. 
al-Mīsawī, Muhammad al-Ṭāhir. Jamharat Maqālāt wa Rasāil Shaykh al-Imām Muhammad al-Ṭāhir Ibn' Āshūr. Vol. 2. Amman: Dār alNafāis li al-Nashr wa Tawzī, 2015.

Muchammad, Abdul Aziz. "Shari'ah dan Tafsir Qur'an: Elaborasi Maqāṣid dalam Tafsir Ibn 'Ashūr." Thesis Post-graduate, Universitas Islam Negeri Syarif Hidayatullah, 2008.

Mulia, Musdah. "Politik Identitas: Ancaman Terhadap Masa Depan Pluralisme di Indonesia." In Politik Identitas dan Masa Depan Pluralisme Indonesia, edited by Ihsan Ali Fauzi. Jakarta: Democracy Project, 2012.

Musolli. "Hegemoni Ideologi dalam Penafsiran Qur'an; Studi Tafsir Syiah dan Tafsir Sunni al-Tahrīr wa al-Tanwīr." Dissertation, Universitas Islam Negeri Syarif Hidayatullah, 2014.

al-Qurțūbī, Abū 'Abdullūh Shams al-Dīn Muḥammad ibn Aḥmad ibn Abī Bakr ibn Farḥ al-Anșārī al-Khazrajī. al-Jāmi' li Aḥkām alQur'ān. Vol. 16. Cairo: Dār al-Kutub al-Mișrīyyah, 1964.

Qurtuby, Sumanto Al. "Catholics, Muslims, and Global Politics in Southeast Asia." Al-Jami'ah: Journal of Islamic Studies 50, no. 2 (December 27, 2012): 391-430.

al-Rāziq, 'Ali 'Abd. al-Islām wa Uṣul al-Hukm. Beirut: Dār Maktabah al-Hayāt, n.d.

Rofiq, Ainur. Tafsir Resolusi Konflik. Malang: UIN Maliki Press, 2011.

Suaedy, Ahmad. Politisasi Agama dan Konflik Komunal: Beberapa Isu Penting di Indonesia. Jakarta: Wahid Institute, 2007.

Suaedy, et.al., Ahmad. Dialog: Kritik dan Identitas Agama. Yogyakarta: Pustaka Pelajar, 1994.

al-Ṭabarī, İmām Abū Ja'far Muhammad ibn Jarīr ibn Yazīd. Jāmi“ al-Bayān fi Ta"wōl ay al-Qur'ān. Vol. 3. Beirut: Dār al-Kutub al'Ilmiyyah, 1999.

al-Tha'ālibī, 'Abd al-'Azīz. Rūḥ al-Taharrur fi al-Qur'ān. Tunis: Dār al-Gharb al-Islāmī, 1985.

al-Tūnisī, Khayr al-Dīn. Aqwām al-Masālik fī Ma'rifah Ahwō̄l alMamālik. Tunis: al-Dār al-'Arabiyyah li al-Kitāb, 2012.

Tūnisiyyah. Dustūr al-Jumhurīyyah al-Tūnisiyyah. Tunis: Majma' alAṭrāsh li al-Kitāb al-Mukhtaṣ, 2014. 
'Ulyān, Bassām Ridwān. “Manhaj ibn 'Āshūr fī al-Qirā'āt fīTafsīrih al-Tahrīr wa al-Tanwīr." Majallat al-Jāmi'ah al-Islāmīyah (Silsilat al-Dirāsāt al-Islāmìyah) al-Mujallad al-Tāsi' 'Ashr, al'Adad al-Thāni (June 2011): 545-573.

"Hay'at min Mudarrisī Jāmi' al-Zaytūna al-Ma'mūr." Al-Majallah al-Zaytūnah, October 1937.

“Tunisia Demographics Profile.” Accessed November 12, 2016. https://www.indexmundi.com/tunisia/demographics_profile.h tml. 